Japan. J. Med. Sci. Biod., 32, 37-45, 1979

\title{
THE INHIBITORY EFFECT OF T-2 TOXIN ON TOLERANCE INDUCTION OF DELAYED-TYPE HYPERSENSITIVITY IN MICE
}

\author{
Minoru OTOKAWA, Yoko SHIBAHARA and Yasuyuki EGASHIRA \\ Department of Pathology, National Institute of Health, \\ Shinagawa-ku, Tokyo 141, Japan
}

(Received: November 25, 1978)

\begin{abstract}
SUMMARY: Mice injected intravenously with $1 \times 10^{\circ}$ sheep red blood cells (SRBC) showed no delayed-type hypersensitivity (DTH) response to SRBC and were unresponsive to DTH induction by sc injection of an optimal dose of SRBC. However, when treated with T-2 toxin, a mycotoxin, 2 days after the iv injection, mice became to show significant DTH response and to be responsive to the DTH induction by the sc injection. When the spleen cells of the mice receiving the iv injection were transferred to unsensitized syngeneic recipients, the DTH response of the recipients to SRBC was suppressed. However, the suppressor activity of the spleen cells was decreased by $\mathrm{T}-2$ toxin treatment.

By the iv injection, cell population of the spleen was increased and that of the thymus decreased. In contrast, by T-2 toxin treatment 2 days after the iv injection, cell population of the spleen was not increased and that of the thymus was markedly decreased.

The ratio of $\theta$-bearing cells was increased in the spleen by the iv injection. However, such increase was not observed after the T-2 toxin treatment. The ratio of Igbearing cells in the spleen was not changed by the iv injection and the $T-2$ toxin treatment after the iv injection. $T-2$ toxin seems to interfere with generation of suppressor cells for the DTH response.
\end{abstract}

\section{INTRODUCTION}

T-2 toxin is one of trichothecene mycotoxins produced by Fusarium species of fungi (Ueno et al., 1972). It is known that trichothecene mycotoxins cause damage to such lymphoid organs as the thymus, lymph node, spleen and bone marrow (Ueno et al., 1971, 1973). In a previous study, T-2 toxin was shown to enhance delayed-type hypersensitivity (DTH) to sheep red blood cells (SRBC) in mice but not to affect hemagglutinin antibody response (Masuko et al., 1977). Cyclophosphamide (CY) is a well-known drug which enhances DTH to SRBC (Askenase, Hayden and Gershon, 1975). Suppressor cells, that are contained in spleen cells from the DTH-tolerant mice, were not present in the mice treated with CY previously (Liew, 1978). In this paper, we describe the inhibition of the tolerance induction of $\mathrm{DTH}$ to $\mathrm{SRBC}$ in $\mathrm{BDF}_{1}$ mice by $\mathrm{T}-2$ toxin treatment after injection with a tolerogeneic dose of SRBC and the

音川 実・柴原葉子・江頭靖之（国立予防衛生研究所 病理部） 
possible relation between the inhibition and the decrease in population of suppressor cells for DTH response.

\section{Materials AND Methods}

Mice: Six to 12-week-old female $\mathrm{BDF}_{1}(\mathrm{DBA} / 2 \times \mathrm{C} 57 \mathrm{BL} / 6)$ mice were used throughout. Mice were supplied by the Shizuoka Laboratory Animal Agricultural Cooperative Association, Hamamatsu City, Shizuoka.

Antigen: Commercial SRBC stored at $4 \mathrm{C}$ in Alsever's solution was washed three times with phosphate-buffered saline immediately before use.

Toxin: T-2 toxin was kindly supplied by Dr. Y. Ueno, Lab. of Microbial Chemistry, Faculty of Pharmaceutical Science, Tokyo University of Science, Tokyo. The toxin dissolved in olive oil was injected intraperitoneally at a dose of $3 \mathrm{mg} / \mathrm{kg}$ or $4 \mathrm{mg} / \mathrm{kg}$ as described previously (Masuko et al., 1977).

Antisera: Anti-BA $\theta$ (Golub, 1971) serum was kindly prepared by Dr. A. Kojima (in press), Department of Pathology, National Institute of Health, Tokyo. Anti-mouse-Ig serum was kindly donated by Dr. S. Tamura, Department of Pathology, National Institute of Health, Tokyo.

Iv injection: To induce DTH tolerance to SRBC, mice were injected into the tail vein with a dose of $1 \times 10^{9} \mathrm{SRBC}$ unless otherwise specified.

Sc injection: To induce DTH response to SRBC, mice were injected subcutaneously into the lumbar and nuchal regions with a dose of $1 \times 10^{8}$ or $2 \times 10^{8}$ SRBC.

DTH test and antibody assay: DTH was measured by footpad swelling. An eliciting dose of $5 \times 10^{7} \mathrm{SRBC}$ in $25 \mu \mathrm{l}$ was injected into the left hind footpad. The increase in footpad thickness was measured $24 \mathrm{hr}$ after the elicitation as described previously (Tamura and Egashira, 1973). Hemagglutinin antibody titers were determined in the sera obtained from mice immediately after measuring footpad swelling. The sera were heat-inactivated prior to titration. Hemagglutinin titration was performed with a microtiter plate as described previously (Tamura and Egashira, 1973).

Preparation of cell suspensions: Suspensions of spleen and thymus cells were prepared by washing out the tissues with a syringe and a pair of tweezers through stainless wire meshes into balanced salt solution (BSS) with $2 \%$ fetal calf serum (FCS). The cells were gently dispersed with a cappillary pipet and centrifuged at $1,000 \mathrm{rpm}$ for $10 \mathrm{~min}$ at $4 \mathrm{C}$. After centrifugation, the cells were washed once in an ammonium chloride solution $\left[0.83 \% \quad \mathrm{NH}_{4} \mathrm{Cl} / 0.17 \mathrm{M}\right.$ Tris(hydroxymethyl) aminomethane (9:1)] to lyse erythrocytes and then washed three times in BSS with 2\% FCS. Viability, as examined by the dye exclusion test with trypan blue, was no less than $80 \%$.

Antiserum treatment: Spleen and thymus cells for cell count and anti-Ig and anti-BA $\theta$ treatment were washed as stated above and resuspended in BSS with $2 \%$ FCS and $0.1 \%$ sodium azide. Spleen cell suspensions $\left(50 \mu 1,2.5 \times 10^{5}\right)$ were mixed with equal volumes of anti-BA $\theta$ serum or anti-Ig serum and comple- 
ment (normal guinea-pig serum), and the mixture were incubated for $30 \mathrm{~min}$ at $36 \mathrm{C}$. After the incubation, the cells were chilled to $4 \mathrm{C}$ and stained with trypan blue and the staining cells were counted. Treatment with anti-Ig to a dilution of $1: 256$ lysed $62.1 \%$ of spleen and $1.6 \%$ of thymus cells from normal mice. Treatment with anti-BA $\theta$ to a dilution of $1: 256$ lysed $26.5 \%$ of spleen and $100 \%$ of thymus cells from normal mice. Anti-Ig and anti-BA $\theta$ serum were not toxic to spleen and thymus cells without addition of complement. Accordingly, both sera were used at 1:250 dilutions.

Cell transfer: Spleen cells for transfer experiments were pooled, washed as stated above and resuspended at a concentration of $2 \times 10^{8}$ viable cells $/ \mathrm{ml}$ in BSS with $2 \%$ FCS. An aliquot of $0.25 \mathrm{ml}\left(5 \times 10^{7}\right.$ cells $)$ of the cell suspension was transferred intravenously to recipients.

\section{RESULTS \\ Effect of Antigen Dose on Tolerance Induction of DTH}

It has been shown that the tolerance induction of DTH to SRBC in mice is highly dependent on the dose and the route of antigen injection (Lagrange, Mackaness and Miller, 1974). The iv injection of a large dose of SRBC induced tolerance to DTH both in outbred CD-1 mice (Lagrange et al., 1974) and inbred CBA mice (Liew, 1977). To find the optimum dose for tolerance induction of $\mathrm{DTH}$ to $\mathrm{SRBC}, \mathrm{BDF}_{1}$ mice were injected intravenously with various doses of SRBC and subcutaneously with $2 \times 10^{8}$ SRBC 7 days later. DTH was elicited in the footpad 7 days after the sc injection. Figure 1A shows that iv injection with $1 \times 10^{8}$ or $10^{9} \mathrm{SRBC}$ inhibited the $\mathrm{DTH}$ response to the sc injection but those injected intravenously with $1 \times 10^{6}$ or $10^{7} \mathrm{SRBC}$ did not. It was, therefore,

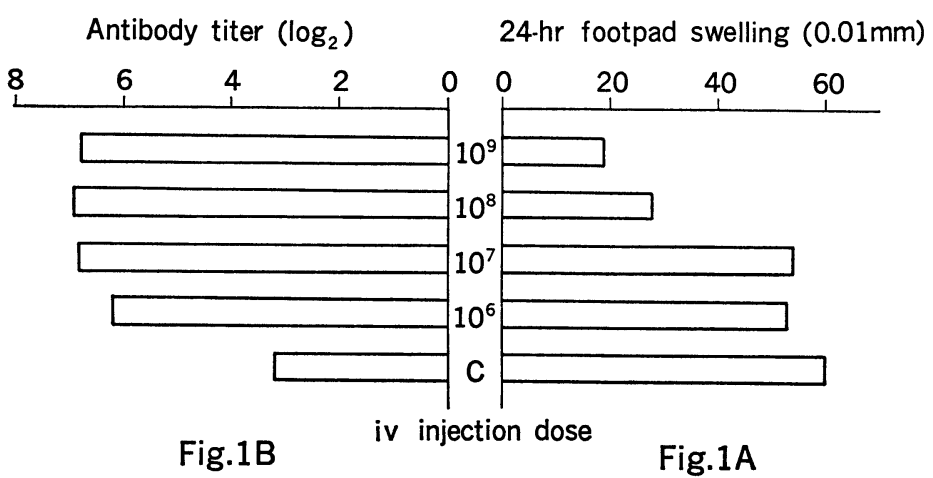

Fig. 1. Tolerance induction of DTH to SRBC. Mice were injected intravenously with various doses of SRBC and 7 days later injected subcutaneously with $2 \times 10^{8}$ SRBC. DTH was elicited in the footpad 7 days after the sc injection. The increase in footpad thickness was measured $24 \mathrm{hr}$ after the elicitation. C: Control mice injected with SRBC not intravenously but subcutaneously. 
decided to use a dose of $1 \times 10^{9} \mathrm{SRBC}$ injected intravenously for tolerance induction of $\mathrm{DTH}$ in $\mathrm{BDF}_{1}$ mice.

On the other hand, hemagglutinin was detected in the sera of all mice injected intravenously almost on the same level, being higher than that observed in mice without iv injection (Fig. 1B).

\section{Effect of T-2 Toxin on Tolerance Induction of DTH}

It has been shown that mice treated with $\mathrm{T}-2$ toxin 2 days after the sc injection of a sensitizing dose of SRBC produced enhanced DTH response to SRBC compared with that of mice not injected with T-2 toxin (Masuko et al., 1977). We studied the effect of T-2 toxin on the tolerance induction of DTH. Mice were injected intravenously with $1 \times 10^{9} \mathrm{SRBC}$ on day 0 , treated with $\mathrm{T}-2$ toxin at different time intervals, and injected subcutaneously with $2 \times 10^{8} \mathrm{SRBC}$ on day 7. DTH was elicited 7 days after the sc injection. As shown in Fig. 2A, the T-2 toxin treatment on day 2 significantly enhanced $(p<0.05)$ the DTH response. The T-2 toxin treatment on day 1 also enhanced the DTH response but the enhancement was not significant. However, T-2 toxin treatment on day 9 (2 days after the sc injection) did not enhance the DTH response at all. As a control experiment, the effects of T-2 toxin on the induction of DTH were investigated in mice not injected intravenously with $1 \times 10^{9} \mathrm{SRBC}$ and treated with T-2 toxin various times before or after the sc injection. The T-2 toxin treatment before the sc injection had no effect on the induction of DTH

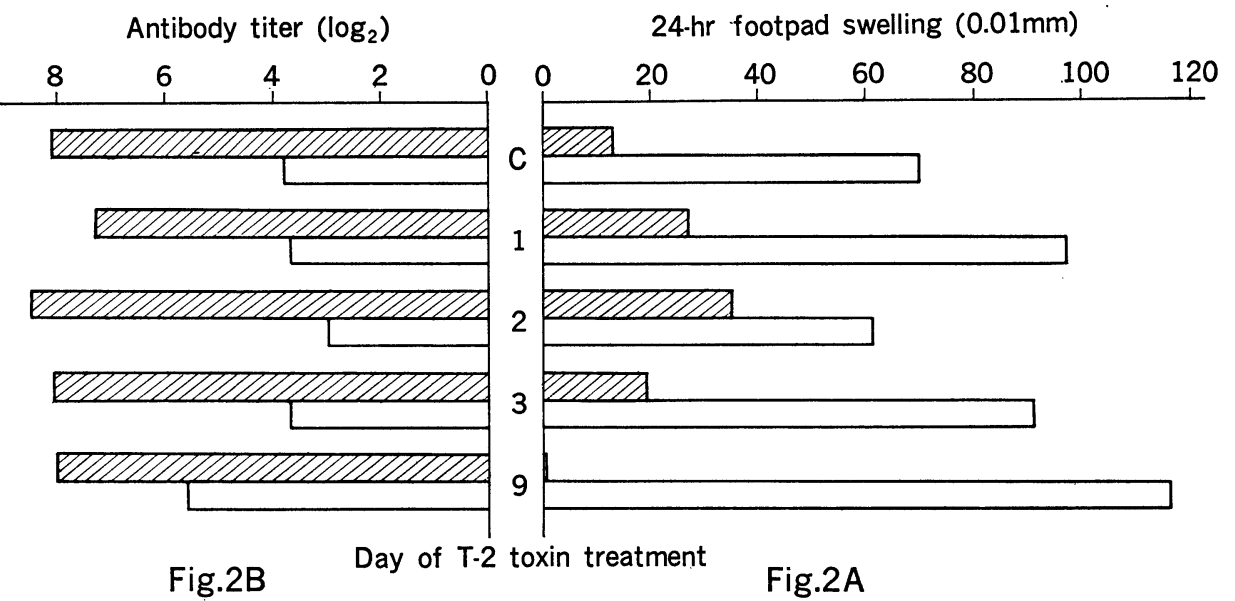

Fig. 2. Inhibition of tolerance induction with T-2 toxin. Mice were injected intravenously with the day indicated. All mice were injected subcutaneously with $2 \times 10^{8}$ SRBC 7 days after the iv injection. DTH response was determined 7 days after the sc injection as in Fig. 1. C: Control mice not treated with T-2 toxin. 


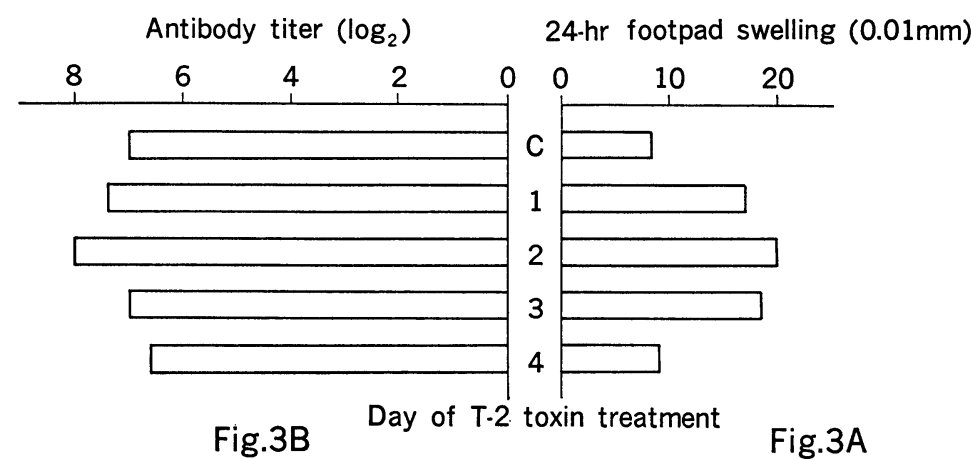

Fig. 3. Inhibition of tolerance induction with T-2 toxin. Mice were injected intravenously with $1 \times 10^{9}$ SRBC and treated with T-2 toxin $(3 \mathrm{mg} / \mathrm{kg})$ on the day indicated. DTH was elicited 10 days after the iv injection and determined as in Fig. 1. C: Control mice not treated with T-2 toxin.

but the T-2 toxin treatment 2 days after the sc injection significantly enhanced $(\mathrm{p}<0.01)$ the DTH response compared with that in mice not treated with T-2 toxin (Fig. 2A).

Hemagglutinin titers were not affected by the $\mathrm{T}-2$ toxin treatment, but high hemagglutinin titers were observed in the sera of mice treated with T-2 toxin 2 days after the sc injection without $1 \times 10^{9} \mathrm{SRBC}$ iv injection, as compared with the level of controls not treated with T-2 toxin (Fig. 2B).

In the next place, mice were treated with $\mathrm{T}-2$ toxin at various time intervals after the iv injection. Ten days after the iv injection, DTH was elicited in the footpad. Figure 3A shows that the iv injection did not induce any DTH; however, DTH response was induced in mice treated with T-2 toxin 2 days after the iv injection $(\mathrm{p}<0.025)$. The $\mathrm{DTH}$ response was also induced by $\mathrm{T}-2$ toxin treatment 1 or 3 days after the iv injection, but not to a significant level (Fig. 3A).

Hemagglutinin titers were almost on the same level in the sera of all groups of mice with or without T-2 toxin treatment (Fig. 3B).

\section{Effect of T-2 Toxin on Suppressor Cells for DTH}

It has been shown that mice injected intravenously with $1 \times 10^{9}$ SRBC produced such cells suppressing DTH, and that these suppressor cells appeared in the spleen in the maximum number 3-4 days after the injection (Liew, 1977). It is thus most likely that the enhancement of DTH by T-2 toxin treatment in the present system is due to the susceptibility of the suppressor cells to T-2 toxin. A preliminary experiment found that spleen cells from mice injected intravenously with $1 \times 10^{9} \mathrm{SRBC} 4$ days previously most effectively suppressed the induction of DTH when the spleen cells were transferred to normal recipients (data not shown). Therefore, spleen cells were obtained as a suppressor 
TABLE I

Effect of T-2 toxin on suppressor cells

\begin{tabular}{clc}
\hline & Cell source & $\begin{array}{c}\text { Footpad swelling in } 24 \mathrm{hr} \\
(0.01 \mathrm{~mm})\end{array}$ \\
\hline A & $\begin{array}{l}1 \times 10^{9} \text { SRBC-primed } \\
\text { spleen cells }\end{array}$ & $46.2 \pm 9.1$ \\
B & $\begin{array}{l}1 \times 10^{9} \text { SRBC-primed and } \\
\text { T-2 treated spllen cells }\end{array}$ & $62.2 \pm 10.9$ \\
C & $\quad-$ & $103.0 \pm 19.5$ \\
\hline
\end{tabular}

Difference between $A$ and $B$ was significant $(p<0.05)$.

source 4 days after iv injection and transferred intravenously $\left(5 \times 10^{7}\right.$ viable cells/mouse) to syngeneic recipients pretreated with cyclophosphamide (CY) 2 days before. Recipients were injected subcutaneously with $1 \times 10^{8}$ SRBC immediately after cell transfer and elicited in the footpad 7 days later. Table I shows that spleen cells from mice injected intravenously suppressed the induction of DTH. Spleen cells from mice treated with T-2 toxin after the iv injection also suppressed the induction of DTH to a significantly less extent $(p<0.05)$.

\section{Effect of T-2 Toxin on Spleen and Thymus}

It has been stated that the thymus-cell traffic to the spleen is increased by iv injection of SRBC into mice (Linna and Cohen, 1973). To study the change in populations of the spleen and thymus cells by the iv injection or by the further T-2 toxin treatment, the spleen and thymus cells were counted. Spleen

TABLE II

Number of thymus and spleen cells after injection of $1 \times 10^{9}$

$\mathrm{SRBC}$ and $\mathrm{T}-2$ toxin treatment $\left(\times 10^{7}\right)$

\begin{tabular}{lcccc}
\hline & $\begin{array}{c}1 \times 10^{9} \text { SRBC } \\
(\text { day } 0)\end{array}$ & $\begin{array}{c}\text { T-2 toxin } \\
(\text { day })\end{array}$ & $\begin{array}{c}\text { thymus } \\
(\text { day } 4)\end{array}$ & $\begin{array}{c}\text { spleen } \\
(\text { day } 4)\end{array}$ \\
\hline I & - & - & 4.5 & 5.1 \\
II & + & - & 3.4 & 5.9 \\
III & + & + & 0.5 & 5.1 \\
\hline
\end{tabular}

\section{TABLE III}

Ratio of Ig- and $\theta$-bearing cells in the spleen after injection of $1 \times 10^{9} \mathrm{SRBC}$ and $\mathrm{T}-2$ toxin treatment

\begin{tabular}{|c|c|c|c|c|}
\hline & \multirow{2}{*}{$\begin{array}{c}1 \times 10^{9} \text { SRBC } \\
(\text { day } 0)\end{array}$} & \multirow{2}{*}{$\begin{array}{l}\text { T-2 toxin } \\
(\text { day } 2)\end{array}$} & \multicolumn{2}{|c|}{$\%$ lysis of spllen cells (day 4) with } \\
\hline & & & anti-Ig serum & anti- $\theta$ serum \\
\hline I & - & - & $65(61-72)$ & $17(13-25)$ \\
\hline II & + & - & $60(55-68)$ & $27(22-35)$ \\
\hline III & + & + & $66(61-75)$ & $19(15-24)$ \\
\hline
\end{tabular}


and thymus cells were obtained from' mice injected intravenously with SRBC 4 days previously and from those further treated with T-2 toxin 2 days after the iv injection. Table II shows that the number of spleen cells increased by the iv injection (not significant) but not by further $\mathrm{T}-2$ toxin treatment, and that the number of thymus cells markedly decreased by the $\mathrm{T}-2$ toxin treatment.

The ratio of Ig-bearing cells and $\theta$-bearing cells to the whole spleen cells was examined. Spleen cells were obtained from the mice used for counting spleen and thymus cells. As Table III shows, the ratio of $\theta$-bearing cells in the spleen from mice injected intravenously 4 days previously was higher than that from normal mice. This increase of the ratio of $\theta$-bearing cells was not observed in the spleen from mice treated with $T-2$ toxin 2 days after the iv injection. The ratio of Ig-bearing cells was not affected by either iv injection or the T-2 toxin treatment.

\section{Discussion}

The mice injected intravenously with $1 \times 10^{9} \mathrm{SRBC}$ showed no $\mathrm{DTH}$ response to SRBC (Fig. 3A) and were unresponsive to DTH induction by sc injection with an optimal dose of SRBC (7 days after the iv injection) (Fig. 2A). T-2 toxin treatment 1-2 days after the iv injection (especially 2 days after that) rendered the mice significantly $\mathrm{DTH}$ responsive and capable of responding to the sc injection. In contrast, T-2 toxin treatment 2 days after the sc injection did not render the mice responsive to the sc injection (Fig. 2A). Therefore, it is probable that $\mathrm{T}-2$ toxin inhibited the induction of $\mathrm{DTH}$ tolerance but had no effect on the tolerant state itself. Antibody production was not affected by the T-2 toxin treatment. Antibody, therefore, does not seem to affect the inhibition of tolerance induction we observed.

A regulatory mechanism for tolerance induction was suggested by the cell transfer experiment. The results of the spleen cell transfer experiments (Table I) indicate that suppressor cells for DTH response were produced by an iv injection of a large dose of SRBC, but decreased by T-2 toxin treatment. The decreased suppressor activity in the spleen seems to explain the enhancement of DTH response observed in the mice treated with T-2 toxin after the iv injection. However, T-2 toxin could not completely inhibit the development of suppressor cells for DTH (Table I). This may explain the partial recovery of tolerance by T-2 toxin (Fig. 2A). The inhibition of the tolerance induction by T-2 toxin is likely to be due to the susceptibility of the suppressor cells or their precursors to T-2 toxin. T-2 toxin probably has an inhibitory effect on the generation of suppressor cells by inhibiting development of their precursors since T-2 toxin was effective only when administered within a few days after antigen stimulation.

The number of thymus cells was decreased by the T-2 toxin treatment. This indicates that T-2 toxin causes greater damage to the thymus than to the spleen. This corresponds with our observation (unpublished) that the weight of the 
spleen decreased a little 1-2 days after T-2 toxin treatment and recovered to the normal level in 4 days but the weight of the thymus decreased greatly and did not recover within a week.

Linna and Cohen (1973) showed that the thymus-cell traffic to the spleen in mice is increased by iv injection of SRBC. The increased ratio of $\theta$-bearing cells in the spleen (Table III) suggests that more thymus cells migrated to the spleen by the iv injection. This assumption is supported by the result demonstrating that the iv injection decreased thymus cells and increased spleen cells in number (Table II). It has been shown that suppressor cells for DTH to SRBC are in the spleen and $\theta$-positive (Liew, 1977). The increased ratio of $\theta$-bearing cells observed in the mice injected intravenously with SRBC was not found in the spleen of the mice treated further with T-2 toxin (Table III). The population of $\theta$-bearing cells thus increased seems to concern the suppressor activity. The decrease in thymus cell population by the T-2 toxin treatment may inhibit the increase in suppressor cell population in the spleen.

The effect of T-2 toxin seems to be transitory because T-2 toxin was most effective when given only 2 days after the iv injection.

\section{ACKNOWLEDGEMENT}

We would like to thank Dr. Y. Ueno for his gift of T-2 toxin. We also thank Drs. S. Tamura and A. Kojima for their gift of antisera. We also thank Miss M. Kimura for her assistance in preparation of the manuscript.

\section{REFERENCES}

Askenase, W. P., Hayden, J. B. and Gershon, K. R. (1975): Augmentation of delayed-typehypersensitivity by doses of cyclophosphamide which do not affect antibody response. J. Exptl. Med., 141, 697-702.

Golub, E. S. (1971): Brain-associated antigen: Reactivity of rabbit anti-mouse brain with mouse lymphoid cells. Cell. Immunol., 2, 353-361.

Kojima, A., Tamura, S. And Egashira, Y. (1979): Regulatory mechanism of delayed-type hypersensitivity in mice. I. Properties of memory cells and suppressor cells for delayed-type hypersensitivity against ovalbumin. Cell. Immunol., in press.

Lagrange, P. H., Mackaness, G. B. ANd Miller, T. E. (1974): Influence of dose and route of antigen injection of the immunological induction of $\mathrm{T}$ cells. J. Exptl. Med., 139, 528-541.

LIEw, F. Y. (1977): Regulation of delayed-type hypersensitivity. I. T suppressor cells for delayedtype hypersensitivity to sheep erythrocytes in mice. Europe. J. Immunol., 7, 714-718.

LIEw, F. Y. AND GILL, H. K. (1978): Regulation of delayed-type hypersensitivity. III. Effect of cyclophosphamide on the suppressor cells for delayed-type hypersensitivity to sheep erythrocytes in mice. Europe. J. Immunol., 8, 172-176.

Linna, T. J. AND Cohen, E. P. (1973): Increased frequency of thymus-derived cells in the spleen of sheep erythrocytes-stimulated mice. Immunol. Commun., 2, 535-546.

Masuko, H., Ueno, Y., Otokawa, M. and Yaginuma, K. (1977): The enhancing effect of T-2 toxin on delayed-type hypersensitivity in mice. Japan. J. Med. Sci. Biol., 30, 159-163.

Tamura, S., Kurata, T., Sugrmoto, M. and Egashira, Y. (1973): Cellular and humoral immune responses in mice. I. Development of delayed-type footpad swelling against sheep erythrocytes and its suppression by intraperitoneal administration of the antigen. Japan. J. Med. Sci. Biol., 26, 161-168.

Tamura, S. AND Egashira, Y. (1975): Cellular and humoral immune response in mice. II. Effect 
of intraperitoneal or subcutaneous injection of carrier on anti-hapten antibody and delayed hypersensitivity responses. Immunology, 28, 934-949.

Ueno, Y., Ueno, I., Irtol, Y., Tsunoda, H., Enomoto, M. And Ohtsubo, K. (1971): Toxicological approaches to the metabolites of Fusaria. III. Acute toxicity of fusarenon-X. Japan. J. Exptl. Med., 41, 521-539.

Ueno, Y., Ishil, K., Sakai, K., Kanaeda, S., Tsunoda, H., Tanaka, T. and Enomoto, M. (1972): Toxicological approaches to the metabolites of Fusaria. IV. Microbial survey on "bean-hulls poisoning of horses" with the isolation of toxic trichothecenes, neosolaniol and T-2 toxin of Fusarium solani M-1-1. Japan. J. Exptl. Med., 42, 187-203.

Ueno, Y., Sato, N., Ishit, K., SaKaI, K., Tsunoda, H. and Enomoto, M. (1973): Biological and chemical detection of trichothecene mycotoxins of Fusarium species. Appl. Microbiol., 25, 699-704. 